\title{
The Future of the IMF and the World Bank
}

Raghuram G. $\operatorname{Rajan}^{1}$

The Bretton Woods sisters, the International Bank for Reconstruction and Development (henceforth the World Bank) and the International Monetary Fund (IMF), were set up in 1944. The original purpose of the former was to help post-World War II reconstruction, the purpose of the latter was to help revive global trade while averting the "beggar-thy-neighbor" exchange rate policies that characterized the inter-war years. Over the years, the World Bank has refocused on helping poor countries grow while the Fund broadly attempts to foster country policies that ensure macroeconomic stability and limit adverse spillovers to the rest of the world.

It still is in the world's self interest to reduce poverty and economic instability in all countries, not just because their effects spread through trade but also because they can be sources of conflict and terrorism, of politically difficult immigration and of environmental degradation. But can multilateral financiers like the World Bank and the IMF help attain these goals?

In the past, they contributed through loans and through economic advice, with the former being the lever through which multilateral institutions forced countries to accept the latter. Over the years, the value of both contributions has eroded, as I will discuss. Multilateral institutions will have to change, doing old tasks in new ways as also performing new tasks such as slowing climate change. Critical to their transformation will be the attitudes of the countries that play the largest role in their governance. These then are the subject of the rest of the paper.

\section{World Bank Lending}

\footnotetext{
${ }^{1}$ I thank, without implicating, Isabel Guerrero and Arvind Subramanian for helpful comments.
} 
In the past, private capital flows were limited, and the World Bank could bridge the gap between a poor country's desired investment and domestic savings with its own money. Indeed, finance was the key missing ingredient in the post-war reconstruction of countries since these countries already had the capability to put it to good use.

But private capital now searches the world for viable projects. And even if a project has some benefits for society that do not enhance private returns, the government can offer monetary compensation for those aspects from its prospective revenues - and if the country is growing, prospective revenues will be higher than today's. Of course, not every project can, or should, be undertaken by the private sector -- it is very hard to entrust certain activities like governance to the private sector because the high powered monetary incentives that typically accompany private contracting could elicit the wrong kind of behavior. Nevertheless, even if undertaken by the government, projects can be privately financed.

In sum then, there are fewer and fewer situations where the missing ingredient for needed projects is finance. If foreign private financing is not forthcoming, it could mean (a) the project is unviable (b) the risk bearing capacity of the private sector is limited (c) the project is deemed too costly given the government support that is on offer (d) the government's promises (including promises not to expropriate) are not credible. Should the World Bank still finance?

Clearly not under (a)! Given the ability of the private sector to securitize and distribute risk, it is not clear that (b) should be a serious concern. If the government support is inadequate, it is up to the government to see if the country can afford the added support, else the project should be shelved. That leaves (d) - which means the fundamental missing ingredient in many projects is not capital but government capability and credibility. 
The World Bank may be better able to rely on government repayment than the foreign private sector. Both World Bank and IMF loans tend to be the last to be reneged on. This implicit seniority stems from a variety of factors - the multilateral organizations have been careful to not lend when a country is in default to them; they have encouraged the view that their loans will be available when all else is shut off so that they should be seen as a form of insurance that is not lightly dispensed with; they have left unspecified their legal options to enforce payment so that the private sector will be reluctant to lend to a country that is in default to multilateral institutions; and they can rely on the moral suasion of their powerful members to persuade a country to not default.

But even if a multilateral lender has greater power to get repaid, should it lend in the normal course where the private sector will not? The answer is not obvious. Clearly, private sector scrutiny adds valuable information about the value of the project that may not be apparent, or may even be ignored by bureaucrats (both international and domestic) who are eager to do a deal. Moreover, while the Bank may come out whole, the collateral damage resulting from an improperly conceived project negotiated by an untrustworthy government will fall on the country's taxpayers or its other creditors. By freeing the government from the impartial scrutiny of the private sector or, temporarily, tax payers, the Bank may do more harm than good.

This is not to say the foreign private sector is angelic in its behavior. But competition exerts powerful discipline on private finance, and where competition is thwarted by corrupt firms and corruptible government officials, there is little the World Bank can do. The World Bank should go in alone only when responsible governments in very poor countries are attempting to undertake social investments that have few immediate payoffs. But where possible, the World Bank should only co-invest with private finance. And instead of being a senior claimant on a 
project's cash flows as is normal practice, with a government guarantee of repayment, the World Bank ought to have its investment at risk if the project does not pan out, so that it has an incentive to do appropriate amounts of due-diligence, project structuring, and monitoring, all areas where the World Bank can contribute immense amounts of experience. Indeed, the International Finance Corporation, an arm of the World Bank Group, already takes equity positions, and there is no reason why the model should not be more widely followed.

\section{IMF Lending and Crisis Prevention}

Because of recent years of growth fuelled by external demand, crises have become a distant memory for emerging markets. But as export-led growth gives way to domestic-demand led growth, vulnerabilities will increase especially if domestic institutional reform does not keep pace. The Fund's role in managing external debt crises may not be history - indeed, the Fund's ability to coordinate lenders, to monitor and advise the borrower, and its greater priority in repayment may allow it to lend in a crisis. However, the IMF's role should shift from intervening in a panic to attempting to prevent a crisis in the first place.

At present, if a country faces financial difficulty and calls on the Fund, the Fund evaluates its needs, negotiates the conditions it will require to ensure the country can regain access to financial markets, and if a "program" is agreed to, initiates lending. Before such negotiations are concluded, though, there is some uncertainty about the quantity of Fund lending a country will have access to and the conditions that will be imposed. Members and financial markets would like more clarity about whether the Fund will lend and, if so, how much.

A second concern potential emerging market borrowers have is that they will be open to

all manner of intrusive conditions if they approach the Fund for a loan, including those motivated 
by the need of powerful members to secure a political or competitive advantage. This was not important when powerful industrial countries could be both borrowers and lenders at different times, for they had the incentive to restrain conditionality, but as industrial countries stopped borrowing in the 1980s, fears about intrusive conditionality, partially vindicated by what was demanded of the Asian countries during the East Asian crisis, have increased.

The Fund has worked hard on streamlining conditionality, but it could do more. A greater focus on identifying which countries have adopted sensible policies in normal times could reduce the need for program conditionality, especially conditionality that aims to change the structure of a country's economy in abnormal times. In a sense, countries earn the trust of the international community through their "ownership" of sensible policies in good times so that the Fund can rely on the country authorities to do what is needed when unexpected adversity hits. This will enable the Fund to move towards more of a system of insurance, where it pre-commits to help well-managed countries up to a certain pre-specified amount, with only light conditionality related to the unanticipated factors that trigger their need.

Such pre-commitment would reduce uncertainty, thus reducing the need for countries to follow distortionary policies to build reserves. Also, the clear signal of a country's policies provided by the assessment, and the fear of loss of insurance if the country deviates from good policies, would give countries an incentive to stay on the straight and narrow, thus reducing potential moral hazard. Finally, the commitments implied in assessments would give the Fund more of an incentive to sharpen them (rather than mask concerns in bureaucratic "Fundspeak").

Some suggest the Fund would always intervene in times of trouble. Even if this is the case, pre-commitment would benefit countries with mature policies by helping them avoid 
trouble and uncertainty. Of course, assessments will also need to be accurate and regular -- a steady deterioration in assessments will give a country time and incentive to shape up, while if assessments are "behind the curve”, an overly rapid reassessment may precipitate crisis. Also, the Fund should retain a seldom-used option to refuse loans if a "material adverse” political change occurred in a country to precipitate crisis. The Fund should not lend into revolutions!

A last concern is that the IMF Board, which would be making the final assessments, is still dominated by those who will never borrow. If reform (see later) takes too long, another alternative would be for emerging countries to pool part of their reserves, and allow commitments by the pool. The Fund's staff would be ideal for suggesting the impartial assessments, but ultimate decisions would be by pool contributors rather than the Fund's Board.

\section{III.Policy Advice}

Let me now turn to policy advice. Here again there are some differences between the Bank and Fund, and many similarities. The Bank offers poor countries advice on development strategy, and on project conceptualization, evaluation, and implementation. Clearly, project evaluation and monitoring is important and its quality will be enhanced if the Bank accepts its share of the risk in a project. But what about advice on development strategy and on the details of its implementation?

There is a growing view that we economists have little useful to say on workable strategies for growth (see William Easterly (2001), for example). Raghuram Rajan and Arvind Subramanian (2007) argue that aid has been ineffective, while Edward Glaeser et al. (2004) suggest that the most recent explanatory variable for underdevelopment, the quality of a country’s political institutions, seems to have had little impact on growth. Grand strategies for 
catalyzing growth are in disrepute. And increasingly, developing countries have well-trained economists who understand this, and are unwilling to take the prescriptions at face value.

In part, the absence of systematic lessons may be because no matter how well-intentioned policy might be, it is filtered through the lens of governance capacity and of political feasibility. Given the various vested interests in the typically unequal societies in developing countries, the latter is especially hard to correct for. So, for example, even if there is little disagreement that sensible macroeconomic policy - moderate inflation, taxes, budget deficits, tariffs, and current account deficits as well as a competitive exchange rate - and social policy - a sound education and healthcare system as well as basic income support for the very poor -- help create a reasonable environment for growth, how to implement policy depends very much on the details of the country’s situation. Cross-country experience can be helpful in describing what has worked elsewhere, but those experiences cannot be translated lock stock and barrel. Moreover, any policy that eventually emerges could well founder on the rocks of implementation.

Multilateral institutions should not just advise on what would be good in an ideal world, but offer a second best solution that recognizes specific political constraints and capacities in the country, and utilizes the knowledge of the political authorities in that country in formulating feasible paths. The true value of World Bank and the IMF advice lies, however, in using their independence from local interests to steer the policies to a better place, thus avoiding the thirdand fourth- best solutions that are the natural wont of politicians.

The multilateral institutions have recognized the need for country “ownership” of policies but veer between an overly aggressive interpretation and an excessively timid one. The overly aggressive interpretation is to demand that governments reach out to a variety of domestic 
organizations, elected and unelected, in formulating a consensual national growth strategy. The result is anodyne country strategy papers formulated so as to offend no one. No country, however democratic, can be governed well this way. The excessively timid approach is to accept whatever the country wants to do, no matter how contrary to economic logic, remonstrating with country authorities only behind closed doors.

An intermediate approach is warranted, where the multilateral institutions encourage strategy formulation by developing country governments, providing support where needed - for example, using their talented economists to offer country-specific analysis that can help advance the public debate over the strategy and even "sell” it. While multilateral institutions should be tolerant of experimentation, if they disagree strongly with elements of the strategy, they should do so publicly and be vociferous about their disagreement. Some may argue that this compromises the role of the multilateral institution as an advisor, and may impair their ability to obtain confidential data from the authorities. At the same time, negotiating strategy behind closed doors compromises the democratic process, breeds public suspicion, and impairs ultimate ownership. A compromise is for the multilateral institution to not reveal confidential data or policies that rely on surprise, but to be completely honest and open about the rest.

I cannot end without discussing an important challenge to the practice of offering broad policy advice. An increasingly influential school believes the importance of factors like education or aid in influencing growth are really unknowable since we do not know if education or aid policies have been implemented effectively (see Abjijit Banerjee (2007)). Instead, we should focus on promoting micro-interventions that have been shown to work through randomized evaluations. 
Randomized evaluations are undoubtedly important in establishing the merit of some programs. But they can only tell us, for example, whether a certain program helps students learn better (and we should be careful about assuming evaluated programs will continue to work over time, can be easily replicable elsewhere, or can be easily scaled up). But whether more learning is beneficial for the country's development objectives is not something that easily lends itself to evaluation (a program may train better doctors, but they may simply emigrate). Moreover, there will be trade-offs and spillovers between programs. For instance, an AIDS prevention strategy may "work" in reducing the number of people who get AIDS but may draw talented medical personnel and resources away from other preventive care. We may get better AIDs prevention but worse healthcare. Even if each intervention "works", the overall set may not. In short, successfully tested micro interventions may still not lead us to our desired macro objectives.

The point is randomized evaluation should be used when feasible, but it will not eliminate the need for commonsense, judgment, and broad experience in devising policy. Sometimes, development may not be able to wait for development research. Policymakers will have to take a position on the need for education, while paying more attention to implementation. Perhaps development is a process of muddling through, having a broad sensible set of policy objectives, experimenting in a variety of ways to find out what seems to work, being alert to possible unforeseen consequences, and scaling successful experiments up (while constantly testing them). Multilateral institutions would have a role in helping formulate objectives, providing the risk capital for experimentation, and in proselytizing about successes (adding caveats about unthinking attempts at replication) elsewhere. Indeed, knowledge through experimentation should be a global public good the World Bank can create (see Nancy Birdsall and Arvind Subramanian (2007)). 


\section{Spillovers}

The IMF was set up to prevent spillovers from competitive exchange rate depreciations that plagued the inter-war years. Clearly, concerns about spillovers from exchange rate policy are not history, witness the current controversy over renminbi-dollar dirty peg. But cross-border capital flows introduce a whole new set of spillovers that the IMF did not have to deal with in the past.

For one, flows can transmit monetary policy across countries. That a large country can export its inflationary policies to countries that peg their exchange rate to it has been a staple concern. But changes in interest rates in industrial countries have also been associated with "sudden stops" of capital inflows to emerging markets. And lax prudential supervision by the authorities in one country and overly credulous (or poorly incentivized) investors from another can spread financial sector losses across borders.

The point is that the rapid increase in trade and cross-border capital flows in recent years have tied countries more closely together. This is not a bad thing for it allows a more stable growth path for the world; recently, productive fast growing industrial countries provided the aggregate demand to lift crisis-hit emerging markets out of trouble, and the latter financed the deficits of the former. But integration means more spillovers from each country's domestic policies.

Greater economic integration will necessitate greater policy dialogue so as to ward off domestic policies that have large adverse spillovers for the rest of the world. So will attempts to create global public goods such as reducing the pace of climate change, eliminating safe havens for the corrupt, and easing economic tensions between countries. The multilateral institutions 
would be ideal locales for such dialogue to take place, with their staff providing the necessary impartial analysis identifying problems and solutions. There are two impediments here.

First, some of the largest industrial countries see themselves as more sovereign than others, and their politicians brook no interference in their own domestic policies, while being fully prepared to use multilateral agencies to intervene in the domestic policies of others. When emerging markets had the need for loans, industrial countries could, and sometimes did, use multilateral agencies for these purposes, and not always for the greater good of the international community. But as emerging markets have built their own reserve hoards, the only countries that have to listen are poor developing countries, and even they have options.

If indeed we are to manage cross-border spillovers or global public goods better, all countries will have to subject their policies to greater scrutiny. For large industrial countries, this will mean a change in mindset for both politicians and the people -- from a fear of globalization and an atavistic resort to the crudest nationalism, to embracing its benefits and accepting the need for more collective management of its consequences. Emerging markets too will need a change in mindset - they have to believe that undertaking actions for the global good does not mean a sacrifice of the economic independence they have so recently gained.

But a second problem is that the multilateral financial institutions, where industrial countries have thus far had power as a vestige of the structures put in place six decades ago, are viewed with suspicion by the non-industrial countries. No real dialogue is likely to be facilitated by them in this environment. Unfortunately, the continued assertion of some industrial countries of their archaic prerogatives has stood in the way of change. Large emerging markets have also not helped by sulking in a corner about their impotence rather than engaging to remedy it. The 
IMF and the World Bank will need substantial governance reform -- not just a realignment of voting quotas with economic importance today but also the free and transparent selection of their heads from the community of nations (rather than the World Bank being headed by an American and the IMF by an European as is the custom today) -- in order to truly be seen as an honest broker. The world sorely needs a new Bretton Woods conference where the objectives, structures, and governance of multilateral institutions are collectively renegotiated.

\section{Conclusion}

The importance of multilateral financial institutions has not diminished, but their role has changed. Instead of being taskmasters who force change by threat of withdrawal of lending, they are better seen as partners to willing and responsible governments, who can provide valuable advice and supplement their advice with risk financing or insurance. They could also undertake impartial analysis to catalyze domestic debate and to set the agenda for international dialogue on issues like cross-border investment and climate change. But to do so effectively, they have to be seen as honest brokers, and thus the need of the hour is governance reform.

\section{References}

Banerjee, Abhijit 2007, Inside the Machine: Toward a new development economics Boston Review, Vol. 32 (2), pp. 12-18

Birdsall, Nancy and Arvind Subramanian, 2007, "From World Bank to World Development Cooperative", http://www.cgdev.org/content/publications/detail/14625.

Easterly, William, 2001, The Elusive Search for Growth: Economists' Adventures and Misadventures in the Tropics, MIT Press, Cambridge MA.

Glaeser Edward L., Raphael La Porta, Florencio Lopez-de-Silanes and Andrei Shleifer, 2004, "Do Institutions Cause Growth ?", Journal of Economic Growth, 9(3), 271-303.

Raghuram G. Rajan and Arvind Subramanian, 2007, "Aid and growth: What does the cross-country evidence really show?", Review of Economics and Statistics, forthcoming. 